Studies in the Genus Phellinus. I. The Identity of Phellinus rickii with Notes on Its Facultative Synonyms

Author(s): Michael J. Larsen and Frances F. Lombard

Source: Mycologia, Vol. 80, No. 1 (Jan. - Feb., 1988), pp. 72-76

Published by: Mycological Society of America

Stable URL: http://www.jstor.org/stable/3807495

Accessed: 14-02-2016 11:36 UTC

Your use of the JSTOR archive indicates your acceptance of the Terms \& Conditions of Use, available at http://www.jstor.org/page/ info/about/policies/terms.jsp

JSTOR is a not-for-profit service that helps scholars, researchers, and students discover, use, and build upon a wide range of content in a trusted digital archive. We use information technology and tools to increase productivity and facilitate new forms of scholarship. For more information about JSTOR, please contact support@jstor.org. 


\title{
STUDIES IN THE GENUS PHELLINUS. I. THE IDENTITY OF PHELLINUS RICKII WITH NOTES ON ITS FACULTATIVE SYNONYMS
}

\author{
Michael J. LARSEN AND Frances F. LOMBARD \\ Center for Forest Mycology Research, Forest Products Laboratory, ' \\ USDA Forest Service, Madison, Wisconsin 53705-2398
}

\begin{abstract}
The name Phellinus rickii (Bres.) David et Rajchenb., based on Poria rickii Bres., is a later homonym of Phellinus rickii Teix. and renamed Phellinus tropicalis M. Lars. et Lomb. The facultative synonyms of the Bresadola name, Phellinus glaucescens Petch and Phellinus flavomarginatus (Murr.) Ryv., were found to represent distinct species. We consider Phellinus ferrugineovelutinus (Henn.) Ryv. to be a nomen dubium. A cultural description of P. tropicalis is provided.
\end{abstract}

Key Words: Phellinus rickii, $P$. tropicalis nom. nov.

In a recent report, David and Rajchenberg (1985) proposed that the combination Phellinus rickii (Bres.) David et Rajchenb., based on Poria rickii Bres. (Bresadola, 1920), replace the presumed earlier synonym Phellinus ferrugineovelutinus (Henn.) Ryv., the type of which is sterile. However, that combination is a later homonym of Phellinus rickii Teix. (Teixeira, 1950). Furthermore, several names of Phellinus species are considered to be facultative synonyms of Poria rickii. David and Rajchenberg (1985) reported that Phellinus glaucescens Petch is "identical" to Poria rickii. Ryvarden and Johansen (1980) listed Phellinus flavomarginatus (Murr.) Ryv. as a synonym of $P$. ferrugineovelutinus.

Our purposes here are (1) to resolve any question concerning the possible synonymy of $\mathrm{Phel}$ linus rickii (Bres.) David et Rajchenb. with $P$. rickii Teix., and (2) to determine whether any of the proposed facultative synonyms would be an appropriate binomial in Phellinus to replace that used by David and Rajchenberg (1985).

\section{MATERIALS AND METHODS}

Microscopic characters of basidiocarps were studied from freeze-microtomed sections mounted either in $2 \% \mathrm{KOH}, 1 \%$ phloxine B, $1 \%$ cotton blue (Johansen, 1940) to test for cyanophily of basidiospores, or in Melzer's reagent (Melzer, 1924, IKI) to test for amyloid or dextrinoid reactions of basidiocarp microstructures.

\footnotetext{
${ }^{1}$ Maintained at Madison, Wisconsin, in cooperation with the University of Wisconsin.
}

Nomenclatural types were studied for all species names. Illustrations were prepared with the aid of a Zeiss drawing tube. Capitalized color names are from Ridgway (1912), and herbarium designations are from Holmgren et al. (1981). Diagnostic characters are italicized to emphasize important differences between the species studied.

The methods employed in studying the cultures were the same as used in previous studies (Davidson et al., 1942). The Key Patterns were based on 2-wk-old cultures inoculated in the centers of Petri dishes on $1.5 \%$ malt extract agar (MEA) and incubated at $25 \mathrm{C}$. The Species Code of Nobles (1965) was based on 6-wk-old cultures inoculated at the sides of the dishes. Extracellular oxidase production was detected by the Bavendamm test described by Davidson et al. (1938), in which the cultures were grown on malt agar containing $0.5 \%$ gallic (GAA) or tannic (TAA) acids. For the constant temperature study, cultures on MEA were placed in incubators at eight temperatures ranging from 16-44 C $24 \mathrm{~h}$ after plating and measured at the end of $7 \mathrm{da}$. Mat diameters are averages of three replications.

\section{TAXONOMY}

Phellinus RICKII Teixeira, Bragantia 10: 120. 1950.

FIG. 1

HOLOTYPE: Brasil, Prov. R. G. Sul, Sao Leopoldo, “in truncis putridis,” Bresadola 282, 1905 (SP, 28309).

Basidiocarp perennial, distinctly pileate, applanate, attenuated to $3 \mathrm{~cm}$ at point of attach- 


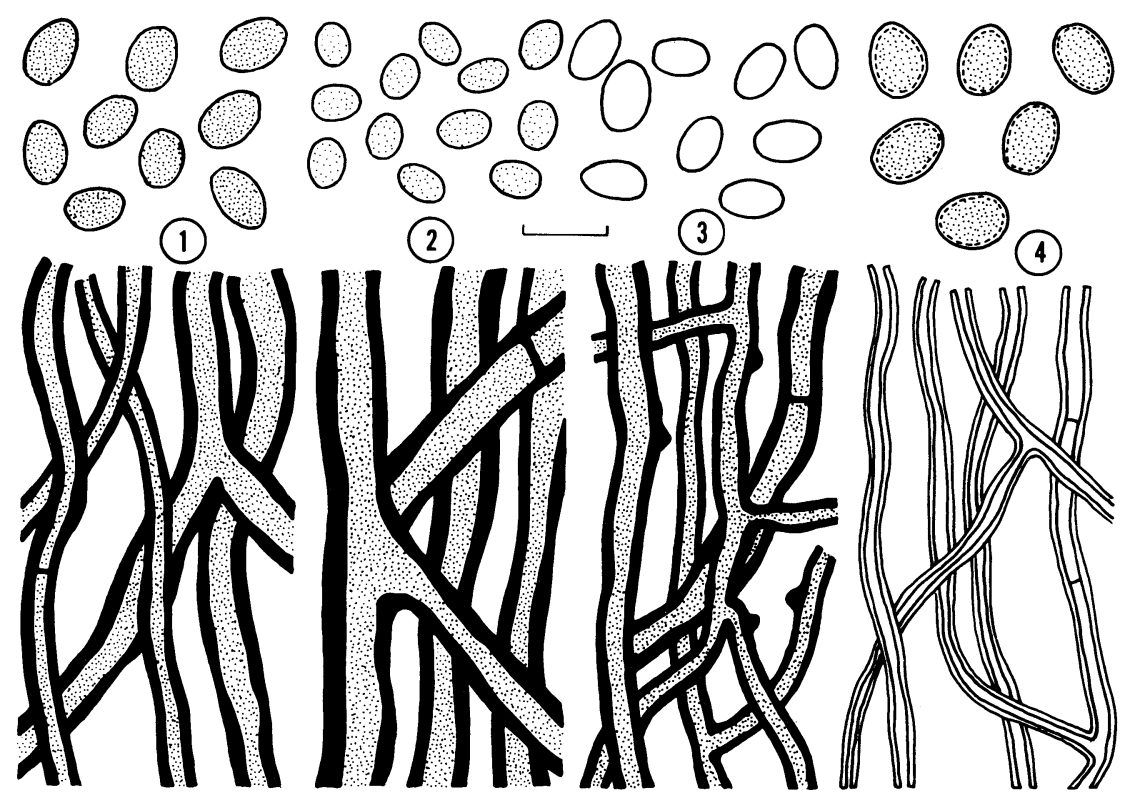

FIGS. 1-4. Basidiospores and context hyphae (as viewed in $2 \% \mathrm{KOH}$ ). 1. Phellinus rickii. 2. P. tropicalis. 3. P. flavomarginatus. 4. P. glaucescens. Scale bar equals $5 \mu \mathrm{m}$.

ment to the substrate, $7 \times 8 \times 2.5 \mathrm{~cm}$; pileus surface concentrically ridged and zonate, dull blackish brown, becoming dull yellowish brown toward the obtuse margin; pore surface dull yellowish brown, paler and brighter toward the margin; pores 4-5 per $\mathrm{mm}$; tube layer indistinctly stratified; context yellowish brown, up to $1 \mathrm{~cm}$ thick; all parts darkening in $2 \% \mathrm{KOH}$.

Clamp connections absent throughout. Hyphae of the context of two kinds: generative, 2$3.5 \mu \mathrm{m}$ diam, simple-septate, pale yellowish brown; skeletal, 2.5-3.5(-4) $\mu \mathrm{m}$ diam, thickwalled, dull brown; tramal hyphae similar to skeletals, 2-3 $\mu \mathrm{m}$ diam, in parallel arrangement; basidia 6-7 $\times 3.5-4 \mu \mathrm{m}$, short-clavate, 4-sterigmate; basidiospores 4-4.5 × 3.5-4 $\mu \mathrm{m}$, broadly ellipsoid to subglobose, thin-walled, pale to dull brown in 2\% $\mathrm{KOH}$ (not pigmented when observed in IKI or distilled $\mathrm{H}_{2} \mathrm{O}$ ), inamyloid, acyanophilous; hymenial setae ventricose, 12-20 × 4.5$6.5 \mu \mathrm{m}$, projecting $2-6 \mu \mathrm{m}$, dark brown.

Phellinus tropicalis M. Larsen et Lombard, nom. nov.

FIG. 2

EPoria rickii Bres., Ann. Mycol. 18: 37. 1920.

[ $\equiv$ Phellinus rickii (Bres.) David et Rajchenb., Mycotaxon 22: 288. 1985. (later homonym)]
HOLOTYPE: Brasil, Sao Leopoldo, in ligno frondoso, J. Rick 14, 1906, "typus" (S); isotype in BPI.

Basidiocarp annual ("or occasionally persisting a second year," teste Lowe, 1966), resupinate, up to $5 \mathrm{~mm}$ thick; pore surface dull brown and becoming paler toward the margin; pores 7-9 per $\mathrm{mm}$; tube layer up to $4 \mathrm{~mm}$ thick; context bright reddish brown, up to $1 \mathrm{~mm}$ thick; all parts darkening in $2 \% \mathrm{KOH}$.

Clamp connections absent throughout. Hyphae of context of two kinds: generative, 2.53.5(-4) $\mu \mathrm{m}$ diam, thin-walled, simple-septate, pale yellowish brown; skeletal, 3.5-4(-4.5) $\mu \mathrm{m}$, thick-walled, infrequently simple-septate, dull yellowish brown; tramal hyphae similar to skeletal except most hyphae thin-walled and parallel in arrangement; thick-walled, dark brown hyphae associated with origin of hymenial setae; basidia 5-6 × 3-4 $\mu \mathrm{m}$, short-clavate, 4-sterigmate; basidiospores $3 \times 2.5 \mu \mathrm{m}$, subglobose, thinwalled, pale yellow to pale brown in $2 \% \mathrm{KOH}$ (not pigmented in IKI or distilled $\mathrm{H}_{2} \mathrm{O}$ ), inamyloid, acyanophilous; hymenial setae (10-)12-14 $(-20) \times 5-7 \mu \mathrm{m}$, abundant, ventricose, projecting up to $8 \mu \mathrm{m}$, dark brown; setae also occurring in clusters or fascicles around pore apertures. 
AdDITIONAL SPECIMENS EXAMINED: BRASIL: Sao Leopoldo, on angiospermous wood, J. Rick 423 (S; cited in original description and bearing "Paratype" on packet, but is not the same fungus as the holotype); Rio Grande do Sul, on hardwood, J. Rick, 1923 (BPI; US 241958); (location not given), on hardwood, J. Rick, 1923 (BPI; US 0241934); Sao Leopoldo, on hardwood, J. Rick, 1930 (BPI; US 0242110); Sao Leopoldo, Rio Grande do Sul, on hardwood, J. Rick 1930 (BPI; US 0242111). COSTA RICA: Tacares near Animas, Heredia Prov., on hardwood, J. L. Lowe $13465,{ }^{2} 16$. viii. 1963 (CFMR, SYRF).

\section{Description of culture.}

Key patterns. -B-P-I-10, B-P-M-7-10.

Species code. -2.6.7.(17).32.37.39.43.54.

Growth characteristics. - Growth on MEA moderately rapid to medium, forming mats $89-90+$ $\mathrm{mm}$ diam in $2 \mathrm{wk}$; mats white at $1 \mathrm{wk}$, creamy white (near Marguerite Yellow) by 2 wk, Deep Colonial Buff to Yellow Ocher by 6 wk, appressed, short-downy, homogeneous, adherent; margins even, indistinct; odorless; no reverse discoloration by $2 \mathrm{wk}$, Honey Yellow to as deep as Mars Brown in streaks and patches by $6 \mathrm{wk}$; oxidase reactions positive, at $1 \mathrm{wk}$ strong on GAA, making no growth to a trace ${ }^{3}$ of growth, moderately strong on TAA, forming mats $24-32$ $\mathrm{mm}$ diam.

Hyphal characteristics. - All hyphae staining in phloxine, simple-septate, of two types: (a) generative hyphae, walls thin, hyaline or pale brown, some cells with walls slightly thickened and contents dark brown, 2-4.5(-6) $\mu \mathrm{m}$ diam; (b) skeletal (?), walls dark brown and slightly thickened, aseptate or sparingly septate, branched, $1-2 \mu \mathrm{m}$ diam; setae rare or absent, brown, narrowly subulate, somewhat thin-walled, $30 \times 4.5 \mu \mathrm{m}$.

Temperature relations. - Average mat diam at 8 constant temperatures: $16 \mathrm{C}, 14.7 \mathrm{~mm} ; 20 \mathrm{C}$, $32.7 \mathrm{~mm} ; 24 \mathrm{C}, 51.3 \mathrm{~mm} ; 28 \mathrm{C}, 71.7 \mathrm{~mm} ; 32$ C, $80.3 \mathrm{~mm} ; 36 \mathrm{C}, 81.0 \mathrm{~mm} ; 40 \mathrm{C}, 42.0 \mathrm{~mm} ; 44$ $\mathrm{C}$, no growth but not killed. Optimum $36 \mathrm{C}$.

Phellinus flavomarginatus (Murr.) Ryv., Norw. J. Bot. 19: 234. 1972. FIG. 3

$\equiv$ Fomitiporia flavomarginata Murr., North American Fl. 9 (1): 11. 1907.

HOLOTYPE: Cuba, Alto Cedro, Santiago de Cuba,

\footnotetext{
${ }^{2}$ Specimen from which a polysporous isolate was obtained and used in this study.

${ }^{3}$ Less than $11 \mathrm{~mm}$ diam including $4-\mathrm{mm}$ inoculum plug.
}

on dead wood in a low dense virgin forest, F. S. Earle and W. A. Murrill, no. 559, 19-20.iii.1905 (NY).

Basidiocarp resupinate, annual (several parts of the type show two layers of tubes, probably caused by alternating wet and dry periods), up to $6 \mathrm{~mm}$ thick, hard and brittle; pore surface umbrinous; pores 7-9 per $\mathrm{mm}$; tube layer up to $6 \mathrm{~mm}$ thick; context less than $1.0 \mathrm{~mm}$ thick, reddish brown with a thin black zone near the substrate; margin bright rusty brown, 1-2 mm wide, pubescent; all parts darkening in $2 \% \mathrm{KOH}$.

Clamp connections absent throughout. $\mathrm{Hy}$ phae of the context of two kinds: generative, 1$1.5 \mu \mathrm{m}$ diam, thin-walled, simple-septate, hyaline to pale yellow; skeletal, 2-3(-3.5) $\mu \mathrm{m}$ diam, dull reddish brown, thick-walled, branched and intertwined, simple-septate but walls often with protuberances that superficially resemble clamp connections; tramal hyphae 3.5-4 $\mu \mathrm{m}$ diam, thickwalled, with parallel arrangement, dull ferruginous brown; basidia 5-6 $\times 4.5-5 \mu \mathrm{m}$, subglobose, 4-sterigmate, hyaline; basidiospores 3$3.5(-4) \times 2-2.5 \mu \mathrm{m}$, broadly ellipsoid to subglobose, flattened adaxially, thin-walled, hyaline in $2 \% \mathrm{KOH}$ (not pigmented in $\mathrm{H}_{2} \mathrm{O}$ or IKI), inamyloid, acyanophilous; hymenial setae rare, 16$18 \times 6.5-7.5 \mu \mathrm{m}$, slightly ventricose, dark ferruginous brown, projecting beyond the hymenium up to $6 \mu \mathrm{m}$; chlamydospores associated with tramal hyphae, intercalary, $7 \times 5 \mu \mathrm{m}$, broadly ovoid, truncate, thick-walled, pale to dull yellowish brown.

Phellinus glaucescens (Petch) Ryv., Norw. $J$. Bot. 19: 234. $1972 . \quad$ FIG. 4

$\equiv$ Poria glaucescens Petch, Ann. Roy. Bot. Gard. Peradeniya 6: 139. $1916(\mathrm{~K})$.

"COTYPE": Ceylon, Hakgala, on hardwood, T. Petch, May 1913 (K; no. 3563 cited in original description, not on packet).

Basidiocarp resupinate, up to $5 \mathrm{~mm}$ thick; pore surface greenish gray with some parts dull brown; margin narrow, pale tan to yellowish brown; pores 7-9 per $\mathrm{mm}$; tube layer up to $5 \mathrm{~mm}$ thick; context not discernible; all parts darkening in $2 \% \mathrm{KOH}$.

Clamp connections absent throughout. $\mathrm{Hy}-$ phae of the context of two kinds: generative, 1.5$2 \mu \mathrm{m}$ diam, thin- to thick-walled, hyaline, branched, simple-septate; skeletal, 1-1.5 $\mu \mathrm{m}$ diam, thick-walled, hyaline in $2 \% \mathrm{KOH}$, rarely branched, septa infrequent; tramal hyphae 2(-2.5) $\mu \mathrm{m}$ diam, thick-walled, simple-septate, dark 
brown, with parallel arrangement; basidia $6 \times 5$ $\mu \mathrm{m}$, subglobose, 4-sterigmate, hyaline; basidiospores 3.5-4(-4.5) × 3-3.5 $\mu \mathrm{m}$, broadly ellipsoid to subglobose, walls noticeably thickened in most spores, inamyloid, acyanophilous; pale yellowish brown to dull brown in $2 \% \mathrm{KOH}$ (somewhat paler in distilled $\mathrm{H}_{2} \mathrm{O}, I K I$ ), hymenial setae 13-15 $(-18) \times 6-8 \mu \mathrm{m}$, ventricose to ventricose-rostrate, thick-walled with walls becoming thinner towards apices, dull reddish brown.

Phiellinus ferrugineovelutinus (Henn.) Ryv., Norw. J. Bot. 19: 234. 1972.

三Poria ferrugineovelutina Henn., Hedwigia 44: 59. 1905.

HOLOTYPE: Brazil, Rio Jurua, Jurua-Miry, on hardwood, E. Ule 2807, viii.1901 (BPI, S).

Lowe (1966), Ryvarden and Johansen (1980), and David and Rajchenberg (1985) have all indicated that the type material is sterile. However, Ryvarden and Johansen (1980) used the name while citing $P$. flavomarginatus as a synonym. David and Rajchenberg (1985) interpreted P. ferrugineovelutinus as a nomen dubium or one that is of uncertain application, and we agree with this disposition of the name. Our study of the type material indicates that it possesses a series of characteristics common to numerous resupinate Phellinus spp. In the absence of basidiospores, however, the name cannot be applied with certainty.

\section{DISCUSSION}

We conclude from our studies of the types of the species in question that Phellinus rickii Teix. is distinct from Phellinus rickii (Bres.) David et Rajchenb. The basidiocarp of $P$. rickii Teix. is perennial, reflexed, and possesses larger basidiospores (TABLE I). Furthermore, P. rickii (Bres.) David et Rajchenb. is a later homonym. Since there appears to be no other available name for the Bresadola species, we propose the new name P. tropicalis M. Lars. et Lomb., typified by Bresadola's (1920) original material.

We further conclude that the synonymy of $P$. glaucescens with Poria rickii Bres., indirectly proposed by David and Rajchenberg (1985), is incorrect. (They stated that "... glaucescens ... . is identical in all respects.") The basidiospores of $P$. glaucescens are larger, and context hyphae are hyaline. Apparently there was doubt, however, concerning this synonymy because David

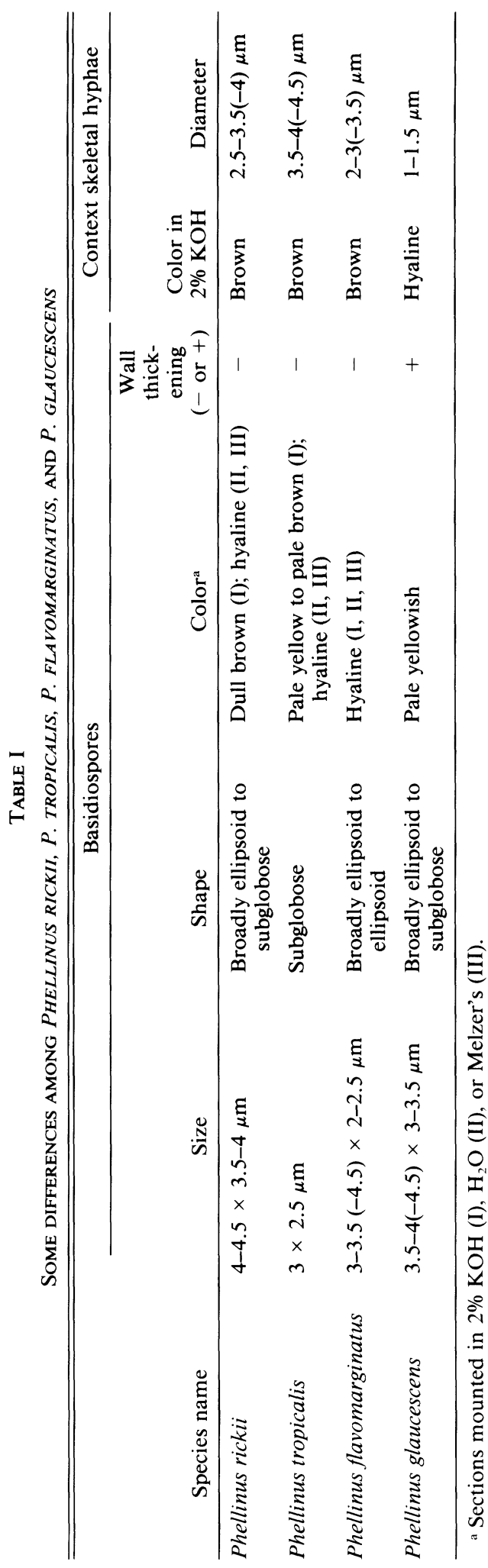


and Rajchenberg (1985) did not select the earlier Petch name. Furthermore, the implied synonymy of $P$. flavomarginatus with Poria rickii Bres. also appears to be incorrect. Instead, these names represent distinct species. The basidiospores of Phellinus flavomarginatus are larger and remain hyaline in alkali. The major differences between the four species studied are presented in TABLE I.

Recent reports (Larsen et al., 1979; David et al., 1982; Niemelä, 1975) strongly suggest that there are a number of misidentified taxa in Phellinus that are extremely similar to recognized species. Similarly, described taxa as presented here may be placed mistakenly in synonymy resulting in broad species concepts. From a recent worldwide literature survey, we determined that there are approximately 275 named Phellinus species, making Phellinus one of the largest genera of wood-destroying fungi. The large number of species and presumed homothallism with concomitant low outbreeding potential suggest a high rate of allopatric speciation.

\section{ACKNOWLEDGMENT}

The loan of specimens from the various herbaria cited herein is gratefully acknowledged.

\section{LITERATURE CITED}

Bresadola, J. 1920. Selecta mycologica. Ann. Mycol. 18: $26-70$.

David, A., B. Dequatre, and J.-L. Fiasson. 1982. Two new Phellinus with globose, cyanophilous spores. Mycotaxon 14: 160-174.

, and M. Rajchenberg. 1985. Pore fungi from French Antilles and Guiana. Mycotaxon 22: 285325.
Davidson, R. W., W. A. Campbell, and D. J. Blaisdell. 1938. Differentiation of wood-decaying fungi by their reactions on gallic or tannic acid medium. $J$. Agric. Res. 57: 683-695.

- - $\longrightarrow$ and D. B. Vaughn. 1942. Fungi causing decay of living oaks in the eastern United States and their cultural identification. USDA Tech. Bull. No. $785.65 \mathrm{p}$.

Holmgren, P. K., W. Keuken, and E. K. Schofield. 1981. Index herbariorum. Part I. The herbaria of the world. 7th Ed. Regnum Veg. 106: 1-452.

Johansen, D. A. 1940. Plant microtechnique. McGraw-Hill Book Co., New York and London. $523 \mathrm{p}$.

Larsen, M. J., F. F. Lombard, and P. E. Aho. 1979. A new variety of Phellinus pini associated with cankers and decay in white firs in southwestern Oregon and northern California. Canad. J. Forest Res. 9: 31-38.

Lowe, J. L. 1966. The Polyporaceae of North America. The genus Poria. State Univ. Coll. For. at Syracuse Univ., Tech. Publ. No. 90. 183 p.

Melzer, V. 1924. L'ornamentation des spores des Russules. Bull. Soc. Mycol. France 40: 78-81.

Niemelä, T. 1975. On Fennoscandian polypores. The Phellinus igniarius complex. Ann. Bot. Fenn. 12: 93-122.

Nobles, M. K. 1965. Identification of cultures of woodinhabiting Hymenomycetes. Canad. J. Bot. 43: 1097-1139.

Ridgway, R. 1912. Color standards and color nomenclature. Published by the author, Washington, D.C. 43 p., 54 pl.

Ryvarden, L., and I. Johansen. 1980. A preliminary polypore flora of East Africa. Fungiflora, Oslo, Norway. 636 p.

Teixeira, A. R. 1950. Himenomicetos BrasileirosV. Polyporaceae-2. Bragantia 10: 113-122.

Accepted for publication August 7, 1987 